UDK 37.02:371

Pregledni rad Primljeno: 15.11.2018.

Revidirana verzija: 4.7.2019. Odobreno za štampu: 5.7.2019.

DOI: https://doi.org/10.46630/gped.1.2019.05

\title{
ДИДАКТИЧКЕ ИНОВАЦИЈЕ КАО ИМПЕРАТИВ УНИВЕРЗИТЕТСКЕ НАСТАВЕ: ПРЕГЛЕД МОДЕЛА И ТЕХНИКА НАСТАВНОГ РАДА
}

\author{
Тамара Вукић ${ }^{1}$ \\ Универзитет у Нишу, Филозофски факултет, Департман за педагогију \\ (студент ДАС)
}

\begin{abstract}
Ancmpaкm: Увођење иновација у различитим подручјима људског деловања, а посебно у области образовања и васпитања представља императив савременог доба, потребу, неопходност и неминовност уколико се као сврха и циљ образовања постави подизање квалитета процеса наставе и учења. Потреба за иновацијама је значајна и за подручје универзитетске наставе која, као највиши степен образовног система, мора бити у корак с временом и оријентисана ка квалитету. Рад представља осврт на карактеристична обележја универзитетске наставе. Анализиран је прелазак са парадигме поучавања на парадигму учења, те истакнута потреба за увођењем дидактичких иновација, односно потреба за смањењем доминантне улоге методе предавања у корист интерактивних модела и техника наставног рада. Поред тога, начињен је покушај систематизације одабраних наставних модела и техника погодних за рад са студентима, а ради прегледности, модели и технике су представљени кроз категорије: иновативни наставни модели, модели развијајуће наставе, иновативни модели вежби, технике за мотивисање и активирање студената и технике комуницирања у малој групи.
\end{abstract}

Кључне речи: универзитетска настава, дидактичке иновације, модели и технике наставног рада, наставници, студенти.

\section{1. Универзитетска настава и „њена“ дидактика}

Универзитетска настава представља сложен, целовит и динамичан систем који за циљ има реализацију образовних и васпитних циљева и задатака, а карактерише је научна заснованост систематски и институционално организоване образовно-васпитне активности која је намењена студентима или полазницима одређеног степена образовања по унапред утврђеном наставном плану и програму (С̌irić, 2013). Реч је о моћном систему којим се развија ново знање, вештине и компетенције свих њених учесника. Другим речима, не уче само студенти, већ све више и наставници и њихови сарадници (Mikanović, 2013).

\footnotetext{
${ }^{1}$ tamaravukic93@gmail.com
} 
Међутим, када се пише о карактеристикама универзитетске наставе, оне су обично представљене у негативном контексту, односно пише се о њеним недостацима. Према наводима Јоргића (2005) у универзитетској настави преовладава метод усменог предавања наставника, у малој мери се користе аудиовизуелне презентације, студенти су пасивни, немају слободу изражавања свог мишљења и критика, недостаје вишесмерна евалуација и самоевалуација како наставника и асистената, тако и самих студената, планирање се врши „одозго“, доминира парадигма поучавања итд.

У центру данашњег високог образовања налази се предавачка настава коју карактерише фронтални облик наставног рада и метода усменог излагања, уз истицање активности које наставник има у наставном процесу (Čirić, 2013). У вези са тиме, може се рећи да је универзитетска настава праћена заблудама: још увек су актуелна схватања да она мора бити предавачка јер се на тај начин остварује високи научни ниво, па се чак сматрало да дидактичка сазнања важе само за школске, али не и за факултетске услове, односно да постоји нека посебна „високошколска дидактика“" за коју не важе уобичајена дидактичка сазнања. Оваква схватања се полако превазилазе. Данас знамо да настава која се своди на предавање представља губљење времена за студенте, као и да се неупоредиво бољи резултати остварују у настави коју карактерише активност студената (Bognar, 2006), те да дидактика, као наука о настави, односно као „педагошка дисциплина која проучава опште проблеме и законитости наставе и учења у њиховом дијалектичком јединству“ (Vilotijević, 1999: 17) важи за све нивое образовања.

\section{2. Парадигма учења насупрот парадигми поучавања у универзитетској настави}

Традиционална парадигма, са строго дефинисаним улогама наставника и студената, и даље доминира у универзитетској настави. Нагласак је на поучавању, предавањима, преношењу готових знања од стране наставника, а студенти су усмерени на запамћивање што већег броја података, односно у центру процеса учења је репродукција знања. Реч је о парадигми поучавања у складу са којом је мисија факултета предаја, испоручивање наставних садржаја студентима (Đukić, 2010).

Први корак у процесу промена је померање фокуса са наставника посматраног као добављач знања на студента који има активну улогу у стицању знања и вештина (Miočinić, 2012) и који ће својим ангажманом и укљученошћу развијати критичко мишљење, креативност, самосталност, компетентност, индивидуалност и др. (Čirič i Nurikić, 2016). Реч је о новим улогама студената и наставника које се дефинишу у оквиру парадигме учења.

Нова улога студената се огледа у томе што они заузимају субјекатску позицију у наставном процесу (Đukić, 2010), они постају субјекти који се све више самоорганизују (Mikanović, 2013) што значи да преузимају одговорност за своје учење и развој, те самоиницијативно дефинишу потребе и циљеве 
учења, проналазе изворе знања, врше одабир стратегија учења и доносе одлуке о начину учења и евалуацији наученог (Ђукић, 2010). Осим тога што студенти морају савладати основна знања, они морају научити како да самостално уче, морају развијати критичко мишљење, као и стручне компетенције. Наведена понашања се разликују од традиционалне наставе утемељене на преношењу знања у чијем центру се налазио наставник (Lalić, 2013).

Од наставника се очекује да користе ефикасне наставне методе, да преузму улогу сарадника, те да студентима помогну у остваривању успеха, подстицањем вештина као што су: постављање циљева, структурисање времена и активности, усклађивање личних аспирација и објективних могућности, измена очекивања и ограничења (Đukić, 2010). Нагласак је на партнерству наставника и студената које се може остварити уколико наставник показује спремност за одступањем од уских оквира застарелих програма, флексибилност у вези са временом потребним за учење, усмереност на квалитет учења уместо на резултате, спремност за решавање неочекиваних ситуација и проблема, као и уколико примењује различите наставне стратегије, методе и поступке (Mikanović, 2013).

Међутим, важно је напоменути да залагање за парадигму учења не значи потпуно одбацивање сваког поучавања (Đukić, 2010). Како наводи Чирић: „(...) у савременој универзитетској настави (...) одговарајуће мјесто и улогу имају и поучавање и учење - критичко, еманципаторско и стваралачко поучавање и учење су нераскидиво испреплетани, баш као удисај и издисај, као образовна и одгојна компонента сваке квалитетне, ефективне и ефикасне наставе“ (С̌irić, 2013: 47).

\section{3. Дидактичке иновације као императив у универзитетској настави}

Са Болоњском реформом нагласак је стављен на интерактивне методе учења, на самостални рад студената, на колаборативне методе, на пројектни рад и сл. (Zupančić, 2016), а наставник има обавезу да проналази нове методе учења и поучавања, начине подстицања и мотивисања студената, као и да иницира и инсистира на пријатељским партнерским односима у свим сегментима универзитетске наставе. Међутим, увођење иновација у методичкој организацији наставе од стране универзитетских наставника је реткост, што је често условљено недовољном стимулацијом и недостатком мотивације за стручним педагошким усавршавањем, иако је то императив савременог доба (С̌irić, 2013). Савремена високошколска настава, како наводи Јовановић (2012: 140): „(...) захтева потпуно другачију организацију од традиционалне, материјалну подршку и надасве оспособљене и мотивисане наставнике и сараднике, који неће само знати већ ће и умети успешно поучавати“.

Мисија факултета више није и не може бити само „предаја“ знања, већ пре његова „производња“, односно учење сваког студента помоћу оног средства које је за њега најефикасније (Đukić, 2010). Савремено образовање мора бити у функцији развоја способности студената за стицање, откривање, креирање, иновирање, производњу и „зарађивање“ знања (Čirić, 2013). Другим 
речима, стратегија поучавања која доминира у традиционалној настави мора бити замењена стратегијом учења и самоучења (Mikanović, 2012). Самим тим, дидактичке иновације у којима се препознаје нова парадигма универзитетске наставе - парадигма учења, треба ставити у центар реформи високог образовања (Đukić, 2010). У складу са тиме, иновирање високог образовања се темељи на дидактичким интервенцијама у следећим подручјима: (1) иновирање наставних планова и програма и дефинисање и примена савремених курикулума; (2) иновирање процеса учења; (3) осавремењивање, иновирање и адекватна примена савремених метода, облика и средстава наставног рада; и (4) обезбеђивање подстицајне наставне и ваннаставне климе (Jovanović, 2012: 135).

\section{4. Метод предавања насупрот иновативним моделима универзитетске наставе}

Од настанка универзитета, па све до краја 20. века у универзитетској настави доминирају предавања чија је основна карактеристика поучавање студената. И поред тога што то не значи да се предавањима није доприносило квалитетном образовању, студентима није могуће, а ни потребно пренети сва научна знања. Из тог разлога, нагласак мора да буде на њиховом мотивисању и оспособљавању за самоусмерено учење, чему могу допринети иновативни модели универзитетске наставе (Mikanović, 2012). Нагласак је на активној улози студената и интерактивности. Предавање више није преовлађујући метод рада, већ се треба користити за употпуњавање интерактивних наставних метода (Zupančić, 2016).

Међутим, како показују истраживања, метод предавања, односно фронтална настава праћена усменим излагањем наставника, и даље доминира у наставном раду на факултетима. У истраживању о наставним методама спроведеном у Словенији (Zupančić, 2016) утврђено је да студенти и даље високо вреднују предавање као најважнију наставну методу, а потом следе интерактивни начини рада у којима је нагласак на међусобном односу између студената и наставника: тимски рад на пројектима, кооперативно учење, теренски излети, групна дискусија итд. С обзиром на то да су студенти ниско вредновали индивидуалне начине рада (рад на тексту, индивидуалне презентације, индивидуални задаци) наспрам метода које захтевају тимски рад, аутор закључује да студенти желе примену метода које се базирају управо на тимском раду. Предавање је високо вредновано, као најбоља наставна метода, од стране студената и у истраживању о наставним методама спроведеном у Пакистану (Sajjad, 2010), а као разлози за такав став издвајају се: наставник пружа сва потребна знања везана за одређену тему, штеди се време, студенти пажљиво слушају наставника и записују итд. Након предавања следи групна дискусија (веће учешће студената, ефикасније учење, нема учења напамет, развија се креативност итд.). Још једно истраживање о наставним методама и начинима рада спроведено у Хрватској (Miočinić, 2012) показује да је, из угла студената, најзаступљенија фронтална настава, а потом следе вођени разговор, дискусија (изражавање личних ставова), интегрисана или интердисциплинарана настава, интерактивно учење, де- 
монстрације са вежбањима итд. Такође, према мишљењу студената, најефикаснији су излети, путовања и екскурзије, потом дискусије, радионице, дебате, интеракитвно учење, демонстрације са вежбањима итд. Студенти су ниско вредновали игре улога, интегрисану или интердисциплинарну наставу, вођене практичне вежбе, дебате, симулације, проблемску наставу, „олују идеја“, што може бити последица непознавања предности оваквих начина рада, с обзиром на то да се примењују ретко или никада. Најмање вредноване су настава на даљину, која захтева иновативне могућности у области информационе и комуникационе технологије, и програмирана настава која захтева велике трошкове, а која није исплатива с обзиром на брзо застаривање знања.

Полазећи од тога да савремену универзитетску наставу карактерише централна позиција студента, потребно је да се у настави више примењују савремене стратегије учења: интегрисано учење, сарадничко учење, пројектна настава, стваралачко учење, истраживачки рад студената и др. педагошки проверени поступци учења и самоучења (Mikanović, 2013). Међутим, како предавачка настава доминира на свим нивоима образовања, студенти, који су од почетка школовања навикнути на фронтални начин рада, склони су томе да га оцене као најпожељнији. Самим тим, предности савремених метода и техника студентима остају непознате што води томе да их ниско вреднују, као у случају поменуте наставе на даљину. И поред тога што настава на даљину може да допринесе томе да студенти развијају самосталност у раду, да се активно образују у оним областима које их посебно интересују, да ступе у контакт са стручњацима из различитих области, те да преузму одговорност за своје лично усавршавање, они остају лишени ових могућности, јер је ипак „најлакше седети и слушати предавање“ и усвојити знања која је неко други, у овом случају професор, већ припремио као готову целину. Професори се, са друге стране, и даље под снажним утицајем традиције и искуства које са собом носе из периода свог школовања, ослањају на предавање, пасивно га прихватајући. Томе доприноси и чињеница да је предавање релативно лако организовати, при чему професор не мора да се суочава са страхом од неизвесности који са собом носе иновативни начини наставног рада.

\section{5. Преглед модела и техника наставног рада са студентима}

Иновативни начини рада данас су многобројни и стоје на располагању свима онима који настоје да и практично превазиђу модел наставе у коме је наставник централна фигура. У наставку је дат преглед одабраних наставних модела и техника погодних за рад са студентима.

\section{1. Иновативни наставни модели}

У приручнику о наставним методама на студијским програмима у области пољопривреде (Cvetković i sar., 2015) дат је предлог иновативних метода рада. У Табели 1 издвојени су они модели који се могу примењивати и на другим факултетима. 


\section{Табела 1. Преглед иновативних наставних модела}

\begin{tabular}{|c|c|}
\hline Студентска дебата & Предавања гостујућег професора \\
\hline $\begin{array}{l}\text { Врста формалне дискусије у оквиру које две } \\
\text { супротстављене групе студената размењују } \\
\text { аргументе који припадају различитим } \\
\text { становиштима у вези са истом темом и при } \\
\text { томе поштују утврђена правила. Приликом } \\
\text { тога, обично студенти не бирају страну коју ће } \\
\text { заступати, већ им се она додељује. }\end{array}$ & $\begin{array}{l}\text { Циљано припремљена и излагања која наставно } \\
\text { особље одређене високошколске институције (или } \\
\text { истраживачког института) презентују студентима } \\
\text { како би их детаљније упознали са одређеним темама } \\
\text { или продубили њихова постојећа знања. }\end{array}$ \\
\hline Истраживачки рад студената & Студија случаја \\
\hline $\begin{array}{l}\text { Студенти се активно укључују у решавање } \\
\text { одређеног питања осмишљавањем и спровођењем } \\
\text { истраживања под менторством наставника. На } \\
\text { тај начин се повезује теоријско и практично } \\
\text { сагледавање проблема. Осим тога, студент } \\
\text { овладава истраживачким вештинама које може } \\
\text { применити и у случају решавања другачијих } \\
\text { проблема. }\end{array}$ & $\begin{array}{l}\text { Облик активног учења који се односи на } \\
\text { проналажење решења и одговора на дато питање, } \\
\text { односно случај - стварни или измишљени. У тој } \\
\text { ситуацији студенти се питају како би реаговали } \\
\text { ако би се нашли у датим околностима, детаљно } \\
\text { описујући потенцијалне изазове и могуће правце } \\
\text { решења. Основна вредност оваквог начина рада } \\
\text { је у томе што се студенти стављају у ситуацију да } \\
\text { одговоре на питање које нема унапред дефинисан, } \\
\text { односно само један тачан одговор. }\end{array}$ \\
\hline \multicolumn{2}{|c|}{ Израда предлога пројекта (симулација пројекта) } \\
\hline 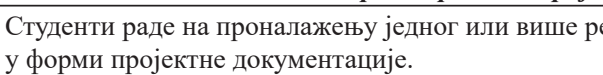 & гења у вези са конкретним \\
\hline
\end{tabular}

(према: Cvetković i sar., 2015, стр. 47-54)

\section{2. Модели развијајуће наставе}

Преглед наставних модела дају и Вилотијевић и Вилотијевић (2016а) називајући их модели развијајуће наставе (проблемска, индивидуализована, програмирана, егземпларна, интегративна, развијајућа настава итд.). У наставку су издвојени и приказани они модели који су погодни за рад у високошколској настави.

\section{Табела 2. Преглед модела развијајуће наставе}

\begin{tabular}{|c|c|}
\hline Модуларна настава & Дистанцна настава (настава на давину) \\
\hline $\begin{array}{l}\text { Наставни модул је логички обликована и } \\
\text { заокружена целина информација и радњи потребна } \\
\text { за стицање знања, умења и навика. Сврха разраде } \\
\text { модула је разлагање одређене теме на компоненте } \\
\text { усклађене са образовно-васпитним задацима, } \\
\text { одређивање савремених наставних метода и } \\
\text { облика за сваку компоненту и интегрисање } \\
\text { свега тога у једну целину. Модул би требало да } \\
\text { обухвати основни или стабилни део (основни } \\
\text { појмови, закони, општа правила...) и промељиви } \\
\text { део (варира у зависности од потреба студената и } \\
\text { техничко-технолошких промена). За сваки модул } \\
\text { припрема се комплет приручних и илустративних } \\
\text { материјала, као и списак неопхоне литературе. }\end{array}$ & $\begin{array}{l}\text { Веза између наставника и студента се успоставља } \\
\text { путем техничких средстава, они су просторно } \\
\text { удаљени. Ова настава најчешће се организује у } \\
\text { виду еластичних курсева различитог трајања у } \\
\text { зависности од циљева и обима програмираног } \\
\text { садржаја. Један курс може чинити више модула } \\
\text { обликованих према одговарајућим наставним } \\
\text { садржајима. У савременој настави на даљину } \\
\text { користе се различити облици комуникација: } \\
\text { електронска пошта, електронски часописи, видео } \\
\text { конференције, крстарење кроз рачунарске мреже, } \\
\text { активни канали за претплату, архиве докумената у } \\
\text { електронском облику. }\end{array}$ \\
\hline
\end{tabular}


Остварује се у кратким наставним јединицама (пет до десет минута) са групом од четири до осам ученика (студенти учитељских и наставничких факултета, запослени наставници, школски надзорници). Овом наставом се симулира наставниково понашање, односно поједине вештине које треба савладати преко једноставних модела.

У лабораторији за микро-наставу на Станфордуниверзитету разрађени су следећи модели:

(1) микро јединица - наставна јединица која траје пет минута и у оквиру које се увежбава само једна наставна вештина; након тога следи њена критичка анализа и планирање њеног поновног извођења са другом групом ученика; затим долази критичка анализа поновног извођења (укупно све траје 45 минута);
(2) микро-клас - долази неколико недеља након микро-јединице, а представља тимску наставу коју реализују три-четири студента који се припремају за наставнички позив (или наставници који се усавршавају); микро-клас чини 12 наставних јединица, а након сваке следи групна анализа како би се утврдиле предности и недостаци;

(3) истраживачка лабораторијска заседања - за циљ имају продубљивање и проширивање знања студената (наставника) о наставним вештинама и њиховој реализацији; кандидати проучавају одређена питања, а о резултатима тих проучавања води се расправа која траје два, три сата.

(према: Вилотијевић и Вилотијевић, 2016а, стр. 143-150; 165-170; 199-202)

\section{3. Иновативни модели вежби}

Осим универзитетских предавања, потребно је иновирати и вежбе, а то је могуће остварити применом неког од иновативних модела вежби које предлаже Микановић (2012).

\section{Табела 3. Преглед новативних модела вежби}

\begin{tabular}{|c|c|}
\hline Експлоративно откривалачка вежба & Проблемска вежба \\
\hline $\begin{array}{l}\text { Прикладна је онда када је наставне садржаје } \\
\text { могуће организовати тако да њихово усвајање } \\
\text { буде засновано на откривању. У оквиру } \\
\text { таквих вежби студенти упознају истраживачке } \\
\text { проблеме, самостално формулишу теме и } \\
\text { подтеме за истраживање, осмишљавају пројекте } \\
\text { и истраживачку методологију, тестирају } \\
\text { хипотезе, спроводе експерименте, учествују у } \\
\text { истраживањима и сл. }\end{array}$ & $\begin{array}{l}\text { Студенти су ангажовани на уочавању односа } \\
\text { између имплицитног и експлицитног, познатог } \\
\text { и непознатог, узрока и последице. У основи } \\
\text { ових вежби је трагање за новим путевима } \\
\text { решавања проблема и откривање законитости, } \\
\text { обележја, појава, процеса, односа, закључака и } \\
\text { генерализација. }\end{array}$ \\
\hline Диферениирана вежба & Егземпларна вежба \\
\hline $\begin{array}{l}\text { Прикладна је за прилагођавање захтева } \\
\text { индивидуалним разликама студената. Организује } \\
\text { се поделом садржаја у нивое: (1) ниво „А“ - 70\% } \\
\text { питања познавања основних програмских садржаја } \\
\text { и } 30 \% \text { питања разумевања и схватања чињеница; } \\
\text { (2) ниво „Б“ - 70\% питања разумевања и схватања } \\
\text { чињеница и 30\% питања учења открићем уз } \\
\text { самосталну примену знања и (3) ниво“В“ - 70\% } \\
\text { питања учења открићем и } 30 \% \text { додатних питања. }\end{array}$ & $\begin{array}{l}\text { Реализује се кроз етапе: (1) идентификација } \\
\text { сличних садржаја и њихова подела на егземпларне } \\
\text { (уже, репрезентативне) и аналогне (шире); (2) } \\
\text { узорна обрада егземпларних садржаја и (3) } \\
\text { самостална студентска обрада аналогних садржаја } \\
\text { који раде по узору који су видели за време } \\
\text { егземпларне вежбе. }\end{array}$ \\
\hline Стваралачка вежба & Партнерска/групна вежба \\
\hline $\begin{array}{l}\text { Најчешће се изводи након заједничких уводних } \\
\text { активности, а заснива се на решавању теоријских } \\
\text { и практичних проблема, осмишљавању идеја и } \\
\text { нових тема, креирању истраживачких пројеката } \\
\text { итд. Посебно је важно да се продукти стваралачке } \\
\text { вежбе презентују пред осталим студентима, да } \\
\text { се заједнички анализира и процени успешност } \\
\text { резултата. }\end{array}$ & $\begin{array}{l}\text { Дидактичке варијанте рада у паровима су: } \\
\text { инструктивни рад студента са студентом, } \\
\text { сарадничко (кооперативно учење) два студента, } \\
\text { индивидуално учење у пару и заједнички } \\
\text { стваралачки рад студената у пару. Групни рад } \\
\text { подразумева поделу студената на групе које раде на } \\
\text { истим или различитим задацима. }\end{array}$ \\
\hline
\end{tabular}




\begin{tabular}{|c|c|}
\hline Дебата & Слагалица \\
\hline $\begin{array}{l}\text { Прикладна је за оспособљавање студената } \\
\text { да аргументују своје ставове, убеђења, идеје, } \\
\text { закључке, предлоге и др. Посебно се издвајају } \\
\text { дебате у којима су супротстављене групе „за“ и } \\
\text { „против“ одређеног става. Остварују се кроз кораке: } \\
\text { (1) припрема дебате и разврставање студената у } \\
\text { групе: позицииона, опозициона и неутрална; (2) } \\
\text { извођење дебате и (3) вредновање дебате. }\end{array}$ & $\begin{array}{l}\text { Методичка структура ове вежбе обухвата: (1) рад у } \\
\text { основним групама (упознавање задатка, летимичан } \\
\text { договор и подела у експертске групе); (2) рад у } \\
\text { специјалистичким (експертским) групама (детаљно } \\
\text { усвајање садржаја); (3) поучавање у основним } \\
\text { групама (сваки студент осталим члановима своје } \\
\text { групе преноси оно што је научио у експертској } \\
\text { групи) и (4) провера нивоа разумевања (водитељ } \\
\text { поставља питања свим студентима). }\end{array}$ \\
\hline Вртешка & Симулација \\
\hline $\begin{array}{l}\text { Примењује се када студенти имају предзнања } \\
\text { о одређеној теми, а прикладна је за развијање } \\
\text { критичког мишљења. Студенти се обично деле на } \\
\text { групе које раде на својим задацима, а потом њихова } \\
\text { решења иду у круг и тада се одвија међугрупна } \\
\text { кружна евалуација.На крају се радни материјал } \\
\text { поново враћа групи која вреднује властита решења. } \\
\text { Такође, могућа варијанта вртешке је да сви } \\
\text { студенти наводе по пример тако што први студент } \\
\text { да неки пример, други чита пример првог и наводи } \\
\text { свој пример, трећи чита примере првог и другог и } \\
\text { наводи свој пример итд. Циљ је доћи до што већег } \\
\text { броја различитих примера. }\end{array}$ & $\begin{array}{l}\text { Од студената се захтева да глуме, симулирају, } \\
\text { имитирају, опонашају одређени догађај, радњу или } \\
\text { процес. }\end{array}$ \\
\hline
\end{tabular}

(према: Микановић, 2012, стр. 49-54)

\section{4. Технике за мотивисање и активирање студената}

\section{У Приручнику за наставнике Handbook for Teachers - Course Structures,} Teaching Methods and Assessment (Hyppönen \& Lindén, 2009) дат је преглед наставних техника рада, од којих су издвојене оне погодне за мотивисање и активирање студената.

\section{Табела 4. Преглед техника за мотивисање и активирање студената}

\begin{tabular}{|c|c|}
\hline Стимулисање писаних задатака & Mane yмa \\
\hline $\begin{array}{l}\text { Студенти добијају задатак да напишу нешто (на } \\
\text { основу свог претходног знања) или да одговоре } \\
\text { на неко питање у вези са одређеном темом. Овај } \\
\text { задатак треба извршити у кратком временском року } \\
\text { (нпр. } 15 \text { мин.), а ова техника се може користити на } \\
\text { почетку или на крају рада на теми. }\end{array}$ & $\begin{array}{l}\text { Приликом креирања мапе ума, најважнији } \\
\text { (суштински) појам се ставља на средину папира, } \\
\text { а остали појмови се повезују са основним у виду } \\
\text { грана. }\end{array}$ \\
\hline Мнемоника (вештина памћења) & Кумулативна група \\
\hline $\begin{array}{l}\text { Различити су начини за подстицање меморије } \\
\text { студената: наставник може описати суштину } \\
\text { предмета проучавања кроз кључне речи, може } \\
\text { креирати асоцијације или менталне слике између } \\
\text { повезаних тема. Такође, могуће је повезивати } \\
\text { ствари на имагинарном нивоу. Наставник може } \\
\text { представити студентима технике за бележење } \\
\text { информација и чињеница (попут мапа ума) и др. }\end{array}$ & $\begin{array}{l}\text { Студенти се поделе у парове и сваки пар добије } \\
\text { задатак, проблем или тему за дискусију. Након } \\
\text { дискусија, парови се формирају у групе (састављене } \\
\text { од два пара), а потом, на крају вежбе, цела група } \\
\text { заједнички дискутује о датим темама. Овакав начин } \\
\text { рада може да обухвати и индивидуалну фазу у којој } \\
\text { сваки студент посебно добије одређено време за } \\
\text { промишљање о проблему, а потом се формирају } \\
\text { парови. }\end{array}$ \\
\hline Саставььье базе знана & Регруписање \\
\hline
\end{tabular}


Студенти извршавају одређени задатак записујући празнине у знању које су се при том појавиле. Након тога се формирају мале групе студената у оквиру којих се долази до заједничког резултата заснованог на ставовима свих чланова групе. Студенти потом размишљају о кључним чињеницама које можда недостају у њиховом коначном резултату и по потреби га употпуњавају.

\section{Кафић за учење}

Столови се разместе по угледу на кафић, а студенти, окупљени у малим групама, седе око столова. За сваку групу се бира по један члан, тзв. секретар групе. Сваки сто добија велики папир или платно и оловке у боји, као и задатак за дискусију. Студенти решавају своје задатке у оквиру група приликом чега сваки од њих може да нешто напише или нацрта на датом папиру. Након одређеног времена, сви, осим секретара, мењају столове. Започиње се нова дискусија за новим столом тако што секретар препричава, односно резимира дискусију претходне групе. Столови се мењају све док сваки од студената не „обиђе““ све столове.

\section{Шетња-презентација}

Студенти се поделе у групе, а свака од њих добија задатак да дизајнира нпр. постер и да га презентује осталим групама. Групе могу добити различите задатке. Важно је да свака група укључи онолико студената колико има група (нпр. пет група од по пет студената). Финални производ се окачи на зид. За презентацију, студенти се регрупишу тако да свака нова група има најмање једног „старог“ члана. Нове групе студената започињу шетњу од постера до постера, а чланови који су учествовали у њиховом креирању презентују закључке остатку групе.
Студенти се поделе у мање групе и свака група добија посебан задатак и упутство за његово извршавање уз истицање предвиђеног времена за то. По завршетку, формирају се нове групе састављене од по једног члана из сваке од претходних група. Нове групе добијају нове задатке којим се претходно добијена решења продубљују или се користе за решавање нових задатака.

\section{Резимеи}

Намењени су продубљивању учења и разумевања. Могу бити у писаној форми, у виду цртежа, усмених презентација и др. Резиме може написати и наставник, (понављање и сумирање неких главних закључака), али се препоручује да их студенти израђују самостално јер је ефикасност учења у том случају већа: студенти морају да анализирају обрађиване теме, да промисле о суштинским чињеницама и да их представе на кохерентан начин, што им може помоћи да попуне празнине у знању.

\section{Дебата уз аргументоване}

Бирају се две опозиционе групе или два појединца који излажу своје ставове о одабраној теми и дају контра-аргументе истовремено вреднујући мишљење друге стране. Циљ није победити противника, већ продубити разумевање. Један студент има улогу председавајућег који осигурава да свако добије прилику да изнесе свој став (у предвиђеном временском року). Уколико се кроз дебату не оствари напредак, председаваујћи може подстаћи остатак студената (публика) да изнесу своје ставове како би се дебата продубила.

\section{Решавање случаја}

Студентима се даје случај који ће обрађивати било индивидуално било у групама. Студенти раде на случају ослањајући се на своје предзнање, али и истражујући нове информације уколико се за то јави потреба. Студентима се могу дати и питања у вези случајева на која морају дати одговоре.

(према: Hyppönen \& Lindén, 2009, pp. 35-55)

\section{5. Технике комунищчирањ а малој групи}

\section{За рад у малој групи посебно су значајне технике комуницирања о који- ма пише Сузић (2005). У Табели 5 су приказане оне погодне за мотивисање студената.}


Табела 5. Преглед техника комуницирања у малој групи (према: Сузић, 2005, стр. 289-294; 296-300)

\begin{tabular}{|c|c|}
\hline 3yj-2pyne & Митраљеска па.ьба \\
\hline $\begin{array}{l}\text { Користе се онда када је потребно активирати } \\
\text { слушаоце у ситуацијама када доминира фронтална } \\
\text { презентација, што ову технику чини погодном за } \\
\text { комбиновање са фронталним радом у настави, } \\
\text { јер не ремети његов ток, а повећава ефикасност. } \\
\text { Учесници се формирају у мале групе које тихо } \\
\text { расправљају (,зује“) о одређеном проблему (у вези } \\
\text { са темом предавања), а потом износе мишљења, } \\
\text { ставове, постављају питања и сл. }\end{array}$ & $\begin{array}{l}\text { Разликује се од буре мозга по томе што учесници } \\
\text { говоре један за другим (други одмах након првог и } \\
\text { тако редом), што захтева да имају спреман одговор } \\
\text { и да знају ко иза кога говори. Може се користити у } \\
\text { фронталној настави како би се ученици накратко } \\
\text { активно укључили у наставу. }\end{array}$ \\
\hline Бура мозга (brainstorming) & Разне форме дискусије. \\
\hline $\begin{array}{l}\text { У овој техници се ослобађају идеје које могу } \\
\text { допринети решавању проблема и зато је важно } \\
\text { да сви учесници говоре све што им падне на } \\
\text { памет. Најпре се пред групу изнесе проблем или } \\
\text { питање које треба решити, а потом треба подстаћи } \\
\text { учеснике да дају што је више могуће одговора. } \\
\text { Вилотијевић и Вилотијевић (2016b) истичу како } \\
\text { се сваки предлог мора саслушати, уважавати } \\
\text { и забележити, а дати предлози се не смеју } \\
\text { коментарисати нити критиковати: сви предлози су } \\
\text { равноправни. }\end{array}$ & $\begin{array}{l}\text { (1) слободна или билијар дискусија - лидер као за } \\
\text { билијарским столом „испали“ проблем или тему } \\
\text { за дискусију, а потом следи „слободно сударање } \\
\text { кугли“, односно слободна размена комуникације; } \\
\text { (2) панел дискусија - један члан (наставник) даје } \\
\text { теоријски и апликативни оквир за тему, а чланови } \\
\text { мале групе потом износе своје сугестије, предлоге, } \\
\text { примедбе и др.; } \\
\text { (3) статична или пинг-понг дискусија - одвија се } \\
\text { у форми комуницирања између две особе, што } \\
\text { значи да у групи комуницирају лидер (наставник) и } \\
\text { поједини чланови; } \\
\text { (4) дискусија укруг - слична је митраљеској паљби, } \\
\text { али није важна брзина давања одговора и могуће } \\
\text { је да неки члан групе не искаже свој став. Након } \\
\text { сваког затварања круга лидер интервенише и } \\
\text { усмерава ток дискусије. }\end{array}$ \\
\hline
\end{tabular}

Термин „бура мозга“ је слободан превод енглеског термина brainstorming. За исти појам се у литератури користе термини „олуја идеја“ (Bognar i Kragulj, 2010), „мождана олуја“ (Vilotijević i Vilotijević, 2016b; Ivić i sar., 2001), „мозгалица“" (Ivić i sar., 2001) или еквивалентна реч преузета из енглеског језика - брејнсторминг. У складу са овим, можда би за технику „митраљеска паљба“ прикладнији термин био „секвенцијална олуја идеја“.

Осим издвојених техника комуницирања, за рад са малом групом студената су погодне и друге технике као што су: дебата, симулације виртуелних ситуација (природни процеси, наставне ситуације, социјални односи итд.), игре улога, радионице, студија случаја, микро-настава, мини-курсеви, теренски рад, драмске групе и практичне вежбе. Када је реч о већим групама студената, погодније је примењивати предавање (уз употребу нових медија и укључивање студената у конверзацију, решавање кратких проблема, резимирање научених садржаја и сл.), интерактивно предавање (студенти се припремају унапред), демонстрације (у комбинацији са вежбама како би се савладале вештине), дебате, дискусије, проблемско учење (учење откривањем), пројектну наставу и интегрисану или интердисциплинарну наставу (Miočinić, 2012).

Без обзира на то да ли је реч о малој и великој групи студената, о предавањима или вежбама, циљ је увек исти: мотивисати студенте за активно 
учешће у раду, подстаћи њихово размишљање, креативност, самосталност, те радозналост, како би не само усвојили наставне садржаје, већ и оне који нису прописани наставним плановима и програмима - како би постали истраживачи оспособљени за перманентно учење у разноврсним областима. Из тог разлога, настава не сме бити искључиво предавачка, јер последице тога могу бити супротне наведеном циљу: код студената се јавља пасивност, зависност, несамосталност, незаинтересованост и досада.

\section{Закључак}

Померање фокуса са наставника на студента, односно прелазак са парадигме поучавања на парадигму учења условило је потребу за променом и у начину рада, односно неопходност примене таквих метода и облика наставног рада којима се промовише активност, интеракција, комуникација студената и, може се рећи, њихова субјекатска позиција у наставном процесу. Самим тим, наглашена је неопходност увођења иновација у наставни процес, а потреба за иновацијама актуелна је и данас, те се може закључити да је реч о перманентном захтеву упућеном свима онима који раде у настави или се наставом баве на посредан начин, без обзира на ниво образовног система.

Један вид иновирања универзитетске наставе представљају модели и технике наставног рада са студентима. У раду је представљен покушај систематизације карактеристичних модела и техника које наставницима стоје на располагању, изложен кроз категорије: иновативни наставни модели, модели развијајуће наставе, иновативни модели вежби, технике за мотивисање и активирање студената и технике комуницирања у малој групи. Наведене категорије формиране су ради веће прегледности предложених модела и техника наставног рада и њихових специфичности.

Приказани и слични модели и технике могу представљати изазов за наставнике, навикнуте на традиционални, фронтални облик рада уз доминантну методу предавања. До тога обично долази због тога што наставници нису упознати са карактеристикама иновативних модела и техника рада, са начином њихове примене, са предностима и могућностима (иако се не смеју занемарити и потенцијални недостаци), те је веома важна њихова промоција, подизање свести наставника о неопходности имплементације промена у раду, како би заиста и дошло до практичне примене ових модела и техника у настави на факултетима. Практична примена иновативних начина наставног рада би, са друге стране, допринела преузимању одговорности за учење, самосталном стицању знања, иницијативи, критичком посматрању проблема, већој креативности, мотивисаности студената, а посредством тога и побољшању квалитета универзитетске наставе. 


\section{Literatura}

Bognar, L. (2006). Suradničko učenje u sveučilišnoj nastavi. Život i škola, 15-16 (1-2), 7-16.

Bognar, L. i Kragulj, S. (2010). Kvaliteta nastave na fakultetu. Život i škola, 24 (2), 169 182.

Cvetković, M., Nastić-Stojanović, J. i Stojanović, M. (2015). Priručnik o nastavnim metodama na poljoprivrednim studijama: Iskustva visokoškolskih institucija iz Srbije i Bosne i Hercegovine. Banja Luka: Univerzitet u Banjoj Luci, Poljoprivredni fakultet.

Čirić, N. (2013). Pedagoške i didaktičko metodičke odrednice kvalitete u organizaciji univerzitetske nastave. Defektologija, 19 (1), 46-50.

Čirić, N. i Nurikić, R. (2016). Nastavna komunikacija i interakcija kao didaktičko-metodički element evaluacije kvalitete u internoj organizaciji savremene univerzitetske nastave. U: I. Rađo (ur.). Međunarodna naučna konfetencija InSEEeed: zbornik radova (93103). Travnik: Edukacijski fakultet.

Đukić, M. (2010). Nova paradigma univerzitetske nastave kao izraz pedagoške reforme visokog obrazovanja. Sociološka luča, 4 (1), 135-145.

Hyppönen, O. \& Lindén, S. (2009). Handbook for Teachers - Course Structures, Teaching Methods and Assessment. Helsinki: University of Technology: Teaching and Learning Development Unit.

Ivić, I., Pešikan, A. i Antić, S. (2001). Aktivno učenje 2: priručnik za primenu metoda aktivnog učenja-nastave. Beograd: Institut za psihologiju.

Jorgić, D. (2005). „Alternativna nastava“ kao model unapređivanja univerzitetskog obrazovanja. U: Nauka i obrazovanje - Banjalučki novembarski susreti (343-356). Banja Luka: Filozofski fakultet.

Jovanović, M. (2012). Didaktika visokog obrazovanja kao temeljna osnova inoviranja i osavremenjivanja vaspitno-obrazovnog rada na savremenom univerzitetu. U: B. Dimitrijević (ur.). Obrazovanje i savremeni univerzitet: tematski zbornik radova (134-144). Niš: Filozofski fakultet.

Lalić, M. (2013). Stavovi studenata prema načinu organizacije nastave u procesu reforme visokog obrazovnja. Metodička praksa, 2, 229-240.

Mikanović, B. (2013). Humanističko-razvojne paradigme univerzitetskog obrazovanja. U: B. Dimitrijević (ur.). Humanizacija univerziteta: tematski zbornik radova (5265). Niš: Filozofski fakultet.

Mikanović, B. (2012). Inoviranje univerzitetske nastave u funkciji kvaliteta obrazovanja. U: B. Dimitrijević (ur.). Obrazovanje i savremeni univerzitet: tematski zbornik radova (44-57). Niš: Filozofski fakultet.

Miočinić, S. N. (2012). Active Teaching Strategies in Higher Education. Metodički obzori, 7 (2), 97-105.

Sajjad, S. (2010). Effective Teaching Methods at Higher Education Level, Pakistan Journal of Special Education. Retrieved (14.05.2018.) from http://class.web.nthu. edu.tw/ezfiles/669/1669/img/1381/1.Effectiveteachingmethodsathighereducationlev el.pdf 
Suzić, N. (2005). Pedagogija za 21. vijek. Banja Luka: TT - Centar.

Vilotijević, M. (1999). Didaktika. Beograd: Naučna knjiga.

Vilotijević, M. i Vilotijević, N. (2016a). Modeli razvijajuće nastave I. Beograd: Učiteljski fakultet.

Vilotijević, M. i Vilotijević, N. (2016b). Modeli razvijajuće nastave II. Beograd: Učiteljski fakultet.

Zupančić, T. (2016). Contemporary Teaching Methods and Knowledge Assessment Methods in Higher Education from the Viewpoint of Students. Život i škola, 62 (2), 109-118.

\title{
DIDACTIC INNOVATIONS AS UNIVERSITY TEACHING IMPERATIVE: THE REVIEW OF TEACHING MODELS AND TECHNIQUES
}

\author{
Tamara Vukić \\ University of Niš, Faculty of Philosophy, Department of Pedagogy (PhD student)
}

\begin{abstract}
Innovations in various fields of human activity, especially in the field of education, can be described as a contemporary imperative, need, necessity and inevitability if the purpose and the goal of education are seen as the improvement of the teaching and learning quality. The need for innovations is also important for university teaching which, as the highest level of educational system, has to be up to date and quality-oriented. This paper represents the review of the characteristics of university teaching. The shift from the teaching paradigm to the learning paradigm has been described, and the need for didactic innovations, i. e. the need to reduce the dominant role of the teaching method in favor of interactive teaching models and techniques, has been emphasized. In addition, an attempt to systemize selected teaching models and techniques suitable when working with students has been made. In order to provide a clean structure, teaching models and techniques are divided into several categories: innovative teaching models, developmental teaching models, innovative models of practicing classes, techniques for motivating and activating students and communication techniques for small groups.
\end{abstract}

Key words: university teaching, didactic innovations, teaching models and techniques, teachers, students

Citiranje članka:

Vukić, T. (2019). Didaktičke inovacije kao imperativ univerzitetske nastave: pregled modela i tehnika nastavnog rada. Godišnjak za pedagogiju, 4(1), 71-83 
